\title{
KAUNO VIDUTINIO AMŽIAUS GYVENTOJŲ FIZINIO AKTYVUMO LAISVALAIKIU RAIŠKA IR JO SĄSAJOS SU SOCIALINIAIS-DEMOGRAFINIAIS VEIKSNIAIS
}

\author{
Edita Maciulevičienė, Kęstutis Kardelis \\ Lietuvos kūno kultūros akademija, Kaunas, Lietuva
}

\begin{abstract}
Edita Maciulevičienė. Lietuvos kūno kultūros akademijos edukologijos krypties doktorantè. Mokslinių tyrimų kryptis — vidutinio amžiaus
\end{abstract} gyventojų fizinio aktyvumo laisvalaikiu sąsajos su socialiniais-demografiniais veiksniais.

\section{SANTRAUKA}

Tyrimo tikslas — ¿vertinti Kauno vidutinio amžiaus gyventoju fizini aktyvuma laisvalaikiu ir atskleisti jo sq̨ajas su socialiniais-demografiniais veiksniais.

Tyrimas atliktas 2001-2005 metais. Buvo tiriama 916 Kauno gyventoju (392 vyrai ir 524 moterys), parinktu atsitiktinès imties büdu (tyrimui pagal Statistikos departamento parengta metodikq ir gautq vyriausybès leidima buvo parinkta 1200 Kauno gyventoju imtis). Tiriamuju amžius - nuo 35 iki 64 metu.

Pagrindinis tyrimo metodas - gyventoju apklausa raštu. Jos metu buvo tiriamas gyventoju požiūris i kūno kultūra ir sporta laisvalaikiu, subjektyvu savo sveikatos vertinima bei i kitus aktyvios fizinès veiklos ypatumus. Tiriamuju buvo prašoma nurodyti, kaip dažnai ir kiek valandu per savaitęjie laisvalaikiu būna fiziškai aktyvūs. Fiziškai pasyviais laikyti asmenys, laisvalaikiu besimankštinantys ar sportuojantys karta per savaitę, per mènesị ar dar rečiau, ir tie, kurie tai dare viena ar mažiau valandu per savaitę. Fiziškai aktyviais buvo laikomi asmenys, laisvalaikiu besimankštinantys ar sportuojantys kasdien, taip pat nuo 2 iki 6 kartu per savaitę arba nuo 2-3 iki 7 ir daugiau valandu per savaitę.

Tyrimo duomenimis, iš Kauno 35-64 metu gyventoju populiacijos fiziškai aktyvūs pagal dažni buvo 23,8\% visu apklaustuju, o fiziškai pasyviu grupe sudarè 76,2\%. Pagal trukmę fiziškai aktyvūs buvo 29,2\%, pasyvūs - 70,8\%. Jauniausios amžiaus grupès (35-44 m.) tiriamieji pasyvesni, lyginant juos su vyresnio amžiaus apklaustaisiais. Vyrai fiziškai aktyvesni negu moterys: fiziškai aktyvūs buvo 59,2\% vyru ir 40,8\% moteru (p <0,001). Pagrindines nepakankamo fizinio aktyvumo priežastys — laisvalaikio stoka, pinigu susimokèti už sportavimo paslaugas trūkumas, tingejimas.

Laisvalaikiu fiziškai aktyvūs gyventojai subjektyviai savo sveikata vertino geriau negu pasyvūs (kaip gerq ir labai gerq ivvertino 75,8\% fiziškai aktyviu ir 61,8\% fiziškai pasyviu apklaustuju — p <0,05). Jauniausios amžiaus grupès tiriamieji savo sveikata vertino kur kas geriau nei vyriausieji (atitinkamai labai gerai ir gerai ìvertino 35,7 ir 15,5\%; p < 0,001). Moteru, vertinusiu savo sveikata labai gerai ir gerai, buvo statistiškai reikšmingai mažiau negu vyru (atitinkamai 21,4 ir 29,8\%; p <0,05). Fizinio aktyvumo laisvalaikiu ir socialiniu-demografiniu charakteristiku lyginamoji analizè atskleidè, kad fiziškai aktyvesni (ir pagal dažni, ir pagal trukme) darbininkai, tarnautojai ir verslininkai, lyginant juos su pensininkais, bedarbiais ir invalidais.

Raktažodžiai: fizinis aktyvumas, subjektyvus sveikatos vertinimas, socialiniai-demografiniai veiksniai.

\section{IVADAS}

$\mathrm{G}$ yvename tokiu metu, kai mokslinè-techninè pažanga vis labiau veržiasi i mūsų buitị, padaro mūsų gyvenimą komfortiš$\mathrm{ku}$. Žmogus greitai pripranta prie komforto ir laiko ji dideliu gèriu. Visgi su šiuo gèriu glaudžiai susijęs judejjimo badas, hipodinamija. Dèl hipodinamijos sumažèja viso organizmo darbingumas, jo atsparumas įvairioms ligoms (Naužemys ir kt., 2000).
Vis didejjantis žinių poreikis verčia daugiau laiko skirti protiniam darbui, todèl mažiau jo lieka fizinei veiklai. Moderniose šalyse paplitęs sèdimas darbas, buities technika ir automatizavimas, kompiuterizacija, ryšių pramonès naujovès sumažino poreiki judèti, išpopuliarèjo pasyvus gyvenimo būdas. Pasyvaus gyvenimo būdo paplitimas visuomenèje privertė domètis, kaip fizinis aktyvumas veikia įvairaus amžiaus žmonių organizmą. Atsi- 
rado nepakankamo fizinio aktyvumo problema (Ainsworth et al., 1993).

Fizinis aktyvumas laisvalaikiu praturtina asmenybės saviraišką, atskleidžia naujų ugdomuju vertybiu turini, kuria naujas elgsenos, bendravimo formas, tobulina judesių kultūrą. Tai ypač svarbu šiuolaikinès visuomenès gyvenime, kuriame vis didesnes perspektyvas turi intelektuali, linksma, energinga, fiziškai tobula asmenybe (Naužemys ir kt., 2000). Dèl to fizinis aktyvumas tampa viena iš pagrindinių individo fizinès, socialinès ir emocinès gerovès sąlygu (Wold, Kannas, 1993).

Taigi pasirinktos temos aktualumas yra siejamas su nepakankamo fizinio aktyvumo problema, kuri mokslineje literatūroje yra nuolat akcentuojama. Tuo tikslu buvo bandoma kurti ir moksliškai pagristi izvairias profilaktinio poveikio programas, galinčias paskatinti gyventojų fizini aktyvumą (Domarkienè ir kt., 2000). Visgi egzistuoja daugelis veiksnių, kurie lemia tokių programų efektyvumą. Jų nežinojimas arba mokslinis nepagrindimas menkina edukaciniu programų rengimą ir jų diegimą. Tokių veiksnių išskyrimas ir jų sąsajų su fiziniu aktyvumu iqvertinimas - svarbi mokslinè problema, kurios tiriamasis klausimas gali būti formuluojamas taip: ar yra vidutinio amžiaus gyventojų fizinio aktyvumo laisvalaikiu ir socialinių-demografinių bei sveikatos rizikos veiksnių tarpusavio ryšys?

Probleminio klausimo formulavimas leido apibrěžti tyrimo objektą, kuriuo pasirinkome vidutinio amžiaus gyventojų fizinio aktyvumo laisvalaikiu ypatumus ir jų sąsajas su socialiniais-demografiniais veiksniais. Šio tyrimo objekto nepriklausomus kintamuosius sudare tiriamujų amžius, lytis, išsimokslinimas ir socialinis statusas, o priklausomus - fizinio aktyvumo laisvalaikiu vertinimas, požiūris į sveikatos stiprinimo priemones.

Tyrimo tikslas - ivertinti Kauno miesto vidutinio amžiaus gyventojų fizini aktyvumą laisvalaikiu ir atskleisti jo sąsajas su socialiniais-demografiniais veiksniais.

\section{TIRTŲJU KONTINGENTAS IR TYRIMO METODAI}

Tiriamujų grupę sudarè 916 Kauno 35-64 metu gyventoju (392 vyrai ir 524 moterys), atsitiktinai parinktų iš visos tiriamosios imties (1200), 2001-2003 m. vykdant gyventojų sveikatos patikrinimą KMU Kardiologijos institute pagal Tarptautinès programos „MONICA“ protokolą. Visi atrinktieji buvo suskirstyti $\mathfrak{i}$ tris amžiaus grupes. Pirmą grupę $(n=238)$ sudare 144 moterys ir 94 vyrai (amžius - nuo 35 iki 44 metu). Antros grupès $(n=321)$ tiriamuju amžius $-45-54$ metai (181 moteris ir 140 vyru $)$, trečios - $(n=366)$ 55-64 metai (176 moterys ir 160 vyru).

Pagrindinis tyrimo metodas - gyventoju apklausa. Taikytas apklausos raštu metodas, kuri sudare 16 klausimų anketa. Apklausos metu tirtas gyventojų požiūris į kūno kultūrą ir sportą laisvalaikiu, subjektyvu savo sveikatos vertinimą bei $\mathfrak{i}$ kitus aktyvios fizinès veiklos ypatumus. Gyventojai buvo apklausiami lankantis jų namuose, iš anksto susitarus dèl vizito. Anketos klausimai tiriamiesiems buvo pateikiami žodžiu, atsakymus pildè apklausos vedejjas. Vykdant apklausą vadovautasi etiniais ir teisiniais tyrimo principais. Visi tyrimo dalyviai informuoti apie tyrimo tikslą, duomenų anonimiškumą. Buvo pabrèžta, kad dalyvavimas tyrime nėra privalomas. Tiriamuju prašyta atsakyti i pateiktus klausimus sąžiningai.

Analizė atlikta fizinio aktyvumo duomenis lyginant su tiriamujų amžiumi, lytimi, jų išsimokslinimu ir socialine padètimi. Fizinis aktyvumas vertintas pagal dažni nurodant, kiek kartų asmuo per savaitę yra fiziškai aktyvus: fiziškai aktyvių grupę sudarè tie, kurie apklausos metu nurodè, kad laisvalaikiu kasdien, 4-6 arba 2-3 kartus per savaitę mankštinasi mažiausiai 30 minučiu taip, kad suprakaituotų ir padažnėtų kvėpavimas, fiziškai pasyvių - tiriamieji, kurie tai darè kartą per savaitę, per mènesi ar dar rečiau. Taip pat fizinis aktyvumas vertintas pagal trukmę nurodant, kiek valandų asmuo per savaitę yra fiziškai aktyvus: fiziškai aktyvių grupę sudare besimankštinantys ar sportuojantys nuo $2-3$ iki 7 ir daugiau valandu per savaitę, o fiziškai pasyvių — tie, kurie tai darè vieną valandą per savaitę ar mažiau. Gyventojų išsimokslinimas buvo skirstomas $\mathfrak{i}$ pradini, nebaigtą vidurini, vidurini, aukštesniji ir aukštaji. Atsižvelgiant i socialinị statusą, tiriamieji suskirstyti į tarnautojų, darbininkų, verslininkų, pensininkų, nedirbančiujų ir invalidų grupes.

Apklausos metu kiekvieno tiriamojo buvo prašoma subjektyviai iqvertinti savo sveikatą pagal šiuos atsakymo variantus: 1 - labai gera, 2 gera, 3 - vidutinè, 4 - bloga, 5 - labai bloga.

Tyrimo duomenims suvesti ir apdoroti buvo naudojama duomenų bazių valdymo sistema SPSS 12.0 for WINDOWS. Lyginant tiriamuju grupes, duomenų skirtumo statistinis reikšmingumas buvo tikrintas naudojant Stjudento $t$ ir chi kvadrato $\left(\chi^{2}\right)$ 
kriterijus. Statistiškai patikimais laikyti atvejai, kai $\mathrm{p}<0,05$.

\section{REZULTATAI}

Tiriant Kauno 35-64 metų gyventojų fizini aktyvumą laisvalaikiu pagal fizinio aktyvumo dažnį nustatyta, kad fiziškai aktyvūs buvo $23,8 \%$ visu apklaustujų, o fiziškai pasyvių grupę sudarè 76,2\% tyrimo dalyvių. Panaši situacija buvo vertinant fizini aktyvumą pagal jo trukmę: fiziškai aktyvūs laisvalaikiu buvo $29,2 \%$, pasyvūs $-70,8 \%$ tiriamuju. Pastebètas fizinio aktyvumo laisvalaikiu trukmès ir apklaustujų amžiaus sąsajų (1 pav.) statistiškai reikšmingas skirtumas.

Pirmame paveiksle pateikti duomenys rodo, kad jauniausios amžiaus grupès tyrimo dalyviai buvo fiziškai pasyvesni, lyginant juos su vyresnio amžiaus tiriamaisiais. Daugiausia laiko (iki 7 valandu per savaitę ir daugiau) fiziniam aktyvumui laisvalaikiu skyrè 45-54 metu gyventojai. Panašūs rezultatai gauti lyginant fizinio aktyvumo dažni laisvalaikiu: aktyviausi vyriausios amžiaus grupès (55-64 m.) tiriamieji $(42,7 \%)$. Kiek ma- žiau aktyvūs 45-54 metų dalyviai (40,4\%), o mažiausiai aktyvūs, kaip ir pagal trukmę, jauniausios amžiaus grupès tiriamieji $(16,9 \% ; \mathrm{p}<0,001$, lyginant su vyriausia ir vidutine grupe).

Statistiškai reikšmingai skyrèsi vyrų ir moterų fizinis aktyvumas laisvalaikiu. Vyru, kurie aktyviai fizinei veiklai laisvalaikiu skirdavo nuo 2 iki 7 ir daugiau valandu per savaitę, buvo $59,2 \%$, o moteru $-40,8 \%(\mathrm{p}<0,001)$. Analogiškas skirtumas nustatytas lyginant fizinio aktyvumo laisvalaikiu dažni (atitinkamai 58,0\% vyrų ir 42,0\% moterų, $\mathrm{p}<0,01)$.

Tiriant fizini aktyvumą laisvalaikiu išsimokslinimo grupèse, statistiškai reikšmingo skirtumo neaptikta. Tarp fiziškai aktyvių tiriamujų, kurie sportavo laisvalaikiu kasdien ar 2-6 kartus per savaitę, nebuvo nè vieno, turinčio pradini išsimokslinima, tuo tarpu pasyviuju grupeje tokiu buvo $1,9 \%$. Pastebèta tendencija, kad aukštaji išsimokslinimą dažniau turejo aktyviai gyventojų grupei priskirti tyrimo dalyviai, lyginant juos su fiziškai pasyviais (atitinkamai 33,3 ir 27,8\%).

Statistiškai reikšmingas skirtumas gautas lyginant fizinio aktyvumo laisvalaikiu dažnį su gyven-
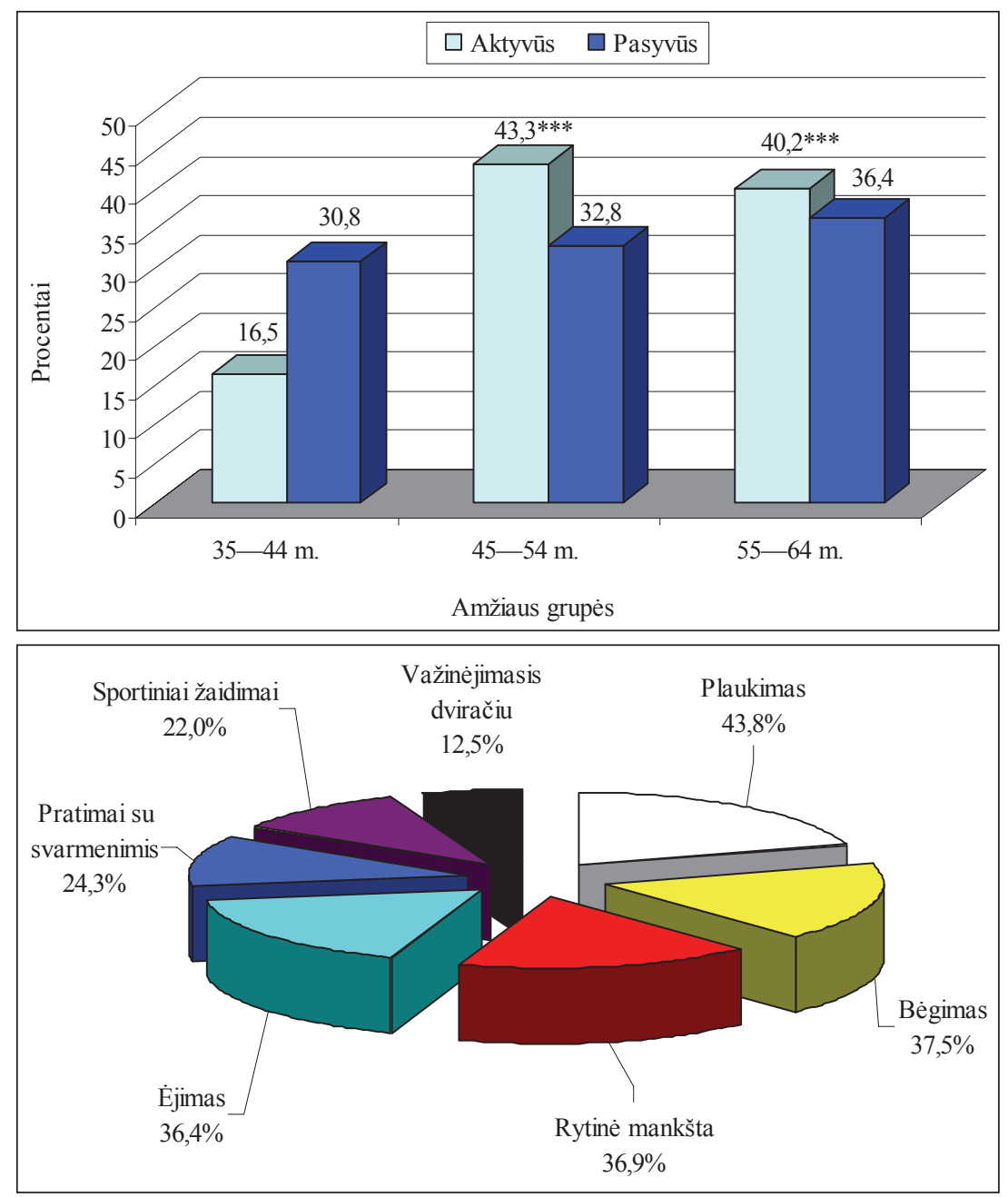

1 pav. Fizinio aktyvumo laisvalaikiu trukmès ir tiriamųjų amžiaus sąsajos

Pastaba. $* * *-\mathrm{p}<0,001$, lyginant su jauniausia amžiaus grupe.

2 pav. Populiariausios fizinio aktyvumo rūšys tarp fiziškai aktyvių Kauno vidutinio amžiaus gyventojų 
Lentelè. Nepakankamo fizinio aktyvumo laisvalaikiu priežastys

\begin{tabular}{|c|c|c|c|c|c|c|c|c|}
\hline \multirow{3}{*}{ Priežastys } & \multicolumn{8}{|c|}{ Atsakymų variantai } \\
\hline & \multicolumn{2}{|c|}{ Taip } & \multicolumn{2}{|c|}{$\mathrm{Ne}$} & \multicolumn{2}{|c|}{ Kartais } & \multicolumn{2}{|c|}{ Iš viso } \\
\hline & $\mathrm{n}$ & $\%$ & $\mathrm{n}$ & $\%$ & $\mathrm{n}$ & $\%$ & $\mathrm{n}$ & $\%$ \\
\hline Laisvalaikio stoka & 384 & 42,9 & 318 & 35,5 & 193 & 21,6 & 916 & 100 \\
\hline Tingèjimas & 338 & 37,8 & 328 & 36,6 & 229 & 25,6 & 916 & 100 \\
\hline Pinigų trūkumas & 262 & 29,3 & 332 & 37,1 & 301 & 33,6 & 916 & 100 \\
\hline $\begin{array}{l}\text { Nori, bet } \\
\text { neprisirengia pradèti }\end{array}$ & 197 & 22,0 & 605 & 67,6 & 93 & 10,4 & 916 & 100 \\
\hline Neleidžia sveikata & 102 & 11,4 & 741 & 83,0 & 50 & 5,6 & 916 & 100 \\
\hline $\begin{array}{l}\text { Nèra sąlygu } \\
\text { mankštintis }\end{array}$ & 81 & 9,1 & 797 & 89,2 & 15 & 1,7 & 916 & 100 \\
\hline Varžymosi jausmas & 54 & 6,0 & 785 & 87,8 & 55 & 6,2 & 916 & 100 \\
\hline $\begin{array}{l}\text { Mano, kad tai } \\
\text { nereikalinga }\end{array}$ & 7 & 0,8 & 886 & 99,0 & 2 & 0,2 & 916 & 100 \\
\hline Nepritaria šeima & 6 & 0,7 & 886 & 99,1 & 2 & 0,2 & 916 & 100 \\
\hline Kitos priežastys & 23 & 24,0 & 73 & 76,0 & - & - & 916 & 100 \\
\hline
\end{tabular}

tojų socialine padètimi. Nustatyta, kad tarnautojai ir verslininkai fiziškai aktyvesni, lyginant juos su pensininkais, bedarbiais ir invalidais (atitinkamai $38,0$ ir $14,1 \% ; p<0,001)$. Visgi dažniausiai fiziškai aktyvūs buvo darbininkų grupès tiriamieji. Šios grupès nariai dažniau buvo fiziškai aktyvūs nei verslininkai ir tarnautojai (atitinkamai 47,9 ir $38 \%$; $<<0,05)$.

Atskirai nagrinètos ir nepakankamo fizinio aktyvumo laisvalaikiu priežastys (žr. lent.).

Lenteleje pateikti duomenys rodo, kad dažniausiai nepakankamo fizinio aktyvumo priežastimi nurodomas laiko trūkumas. Moterys pastaraja priežasti nurodo kur kas dažniau nei vyrai (atitinkamai 47,3 ir 37,5\%; p <0,01). Atsižvelgiant i gyventojų amžių, dažniausiai laiko trūkumą pabrěžia jauniausios amžiaus grupès tiriamieji, lyginant su vyriausia amžiaus grupe (atitinkamai 54,2 ir 31,5\%; p <0,01). Kiek rečiau nurodomas pinigu trūkumas ir tingèjimas. Dažniau pinigų trūkumą nurodo moterys negu vyrai (atitinkamai 32,7 ir 24,7\%; p < 0,05) ir vyriausios amžiaus grupès tiriamieji, pastaruosius lyginant su jauniausia amžiaus grupe (atitinkamai 36,9 ir $17,2 \% ; p<0,001)$. Nors statistiškai reikšmingo skirtumo ir nenustatyta, tačiau pastebima tendencija, kad moterys kiek dažniau negu vyrai tingi būti fiziškai aktyvios (atitinkamai 39,9 ir 35,2\%). Jauniausia amžiaus grupe statistiškai reikšmingai labiau tingi lyginant ją su vyriausia amžiaus grupe (atitinkamai 52,9 ir $32,7 \% ; p<0,001)$. Rečiausiai nurodomos tokios nepakankamo fizinio aktyvumo priežastys kaip varžymosi (nepatogumo) jausmas, šeimos nepritarimas ir manymas, kad tai nereikalinga.

Apklausos duomenys leido išsiaiškinti, kurios fizinio aktyvumo rūšys yra populiariausios tarp laisvalaikiu fiziškai aktyvių vidutinio amžiaus gyventojų (2 pav.).

Iš 2 paveiksle pateiktų duomenu matyti, kad daugiausia laisvalaikio tiriamieji skiria tradicinèms fizinio aktyvumo rūšims: plaukimui, bègimui, ejimui ir rytinei mankštai. Kasdien arba keletą kartų per savaitę rytais mankštinasi daugiau vyrų nei moteru (atitinkamai 30,1 ir 17,4\%; $\mathrm{p}<0,001$ ), o vyriausios amžiaus grupès dalyviai tai daro kur kas dažniau nei jauniausios (atitinkamai 28,9 ir $14,3 \% ; p<0,001)$. Dažniau rytinę mankštą daro tarnautojai, verslininkai ir darbininkai, lyginant juos su pensininkais, bedarbiais ar invalidais, tačiau statistiškai reikšmingo skirtumo šiuo aspektu nenustatyta (atitinkamai 24,1, 24,7 ir 18,0\%). Panaši tendencija pastebima tarp vyrų ir moteru, taip pat tarp amžiaus grupių tiriamujų požiūrio ì bėgimą ir ejjimą. Plaukimo pomègis tarp vyru, moterų ir amžiaus grupèse statistiškai reikšmingai nesiskiria. Natūralu, kad rečiau buvo nurodomos sezoninès fizinio aktyvumo rūšys: slidinejjimas $(0,1 \%)$, čiuožimas $(0,1 \%)$, turistiniai žygiai $(0,2 \%)$ ir meškeriojimas $(1,8 \%)$. Kiek didesnis procentas apklaustujų nurodè dirbantys sode, namie ar ūkyje (17,9\%).

Statistiškai reikšmingas skirtumas pastebètas lyginant fizinio aktyvumo laisvalaikiu duomenis su tiriamujuc subjektyviu sveikatos vertinimu. Moterų, vertinusių savo sveikatą labai gerai ir gerai, buvo statistiškai reikšmingai mažiau negu vyrų (atitinkamai 21,4 ir 29,8\%; p <0,05), o vyrai rečiau savo sveikatą vertino vidutiniškai (atitinkamai 57,7 ir $65,0 \% ; p<0,05)$. Labai blogai ir blogai savo sveikatą vertino $13,6 \%$ moteru ir $12,5 \%$ vyru. Jauniausios amžiaus grupès tiriamieji savo sveikatą vertino kur kas geriau nei vyriausios (atitinkamai labai gerai ir gerai ivertino 35,7 ir 
$15,5 \% ; p<0,001)$. Mažiau ryškus skirtumas tarp amžiaus grupių pastebètas gyventojams vertinant savo sveikatą kaip vidutinę. Tuo tarpu vertinančiu savo sveikatą blogai ir labai blogai vyriausioje amžiaus grupeje buvo 19,6\%, o jauniausioje - tik $6,3 \%(\mathrm{p}<0,001)$. Dauguma tyrimo dalyvių, kurie laisvalaikiu buvo fiziškai aktyvūs, savo sveikatą ivertino kaip gerą ir labai gerą $(75,8 \%)$. Rečiau gerai savo sveikatą vertino fiziškai pasyvūs gyventojai - 61,8\% $(\mathrm{p}<0,05)$.

Laisvalaikiu fiziškai aktyvesni gyventojai dažniau domejosi literatūra apie aktyvią fizinę veiklą. Démesingai skaite knygas, publikacijas apie sporta ir fizini aktyvumą 26,3\% fiziškai aktyvių ir $2,2 \%$ pasyvių tyrimo dalyvių ( $<<0,001)$. Tokio pobūdžio literatūra visiškai nesidomèjo $4,2 \%$ fiziškai aktyvių ir 16,3\% pasyvių tiriamuju $(\mathrm{p}<0,05)$. Fiziškai aktyvūs gyventojai taip pat dažniau nei pasyvūs nurodè, kad norètų klausytis paskaitų apie fizinių pratimų naudą (atitinkamai $20,7$ ir $4,0 \%$; $<<0,001)$.

\section{REZULTATŲ APTARIMAS}

Analizuojant Kauno 35-64 metų gyventoju fizinio aktyvumo laisvalaikiu dažni ir trukmę pastebejjome, kad fiziškai aktyvių tyrimo dalyvių buvo mažiau nei pasyvių. Vyrai daug aktyvesni nei moterys. Taip pat jauniausios amžiaus grupès (35-44 m.) tiriamieji buvo pasyvesni, lyginant juos su vyresnių amžiaus grupių gyventojais. Šiuos duomenis patvirtina ir kitu autorių atlikti tyrimai, kurių duomenys rodo, kad nepakankamo fizinio aktyvumo paplitimas būdingesnis moterims, nacionalinèms mažumoms ir žemo išsimokslinimo asmenims (Tamošiūnas, 1997). Anglijoje atlikti tyrimai parodè, kad fiziškai aktyvių vyrų buvo statistiškai patikimai daugiau negu moterų. Aptiktas ir fizinio aktyvumo ryšys su išsimokslinimu, t. y. pastarajam didejant gereja ir fizinis aktyvumas (Kuh, Cooper, 1992). Atsižvelgiant i socialinę padèti nustatyta, kad laisvalaikiu fiziškai aktyviu tarnautojų ir verslininkų buvo kur kas daugiau nei pensininkų, bedarbių ir invalidų. Darbininku grupeje nustatytas dar didesnis laisvalaikiu aktyviu tiriamuju procentas nei verslininku ir tarnautoju grupèje. Šiuo požiūriu aktyvūs darbininkai dar labiau nutolo nuo nepakankamai fiziškai aktyvių pensininkų, bedarbių ir invalidu grupès.

Buvo analizuojamos nepakankamo fizinio aktyvumo laisvalaikiu priežastys. Dažniausia nepakankamo fizinio aktyvumo priežastimi buvo nurodomas laiko trūkumas. Atsižvelgiant ì gyventojų amžių, laiko trūkumas būdingesnis jauniausioje (35-44 m.) amžiaus grupeje, lyginant su vyriausia $(55-64$ m.). Šiek tiek rečiau buvo nurodomas pinigų trūkumas ar tingèjimas. Kitų autorių tyrimai parodè, kad daugelis vidutinio amžiaus žmonių tiesiog nejaučia nei kūno kultūros, nei kitų fizinio aktyvumo rūšių poreikio ir nesupranta mankštos reikšmès savo kasdienejje veikloje (Gaigalienè, 1997). Autorès duomenimis, iš 608 apklaustuju tik kas penktas gerą sveikatą siejo su fiziniu aktyvumu. Likusieji $(75,8 \%)$ buvo ¡̇sitikinę netgi priešingai - nevertino fizinio pajègumo kaip sveikatos komponento ir mané, kad jei sveikata puiki, tai turi būti geras ir fizinis pajègumas, o jei sveikata pablogeja, tai nyksta ir fizinis pajègumas. Tokių asmenų issitikinimu, sveikatą ir fizini pajègumą reikia taisyti vaistais ir pasyviu poilsiu. Užsiimti fizine veikla galima tik pasveikus ir visiškai sustiprèjus (Gaigalienè, 1999).

Mūsų tyrimo duomenimis, fiziškai aktyvių grupei priskirti gyventojai daugiausia savo laisvalaikio skiria tokioms tradicinèms fizinio aktyvumo rūšims kaip plaukimas, bejgimas, ejjimas ir rytinè mankšta. Tačiau lieka neaišku, ar žmonès Lietuvoje turi pakankamai žinių apie fizinius pratimus, labiausiai tinkamus pagal jų sveikatos būklę. Civilizuotose šalyse didžiausios lèšos skiriamos pirminei ligu profilaktikai ir pacientu mokymui. Sudaromos ivairios mokymo programos, kurias kuruoja ne tik šeimos gydytojai, bet ir bendrosios praktikos slaugytojai. Organizuojamos iškylos i gamta, kuriu metu rengiami mokymai, kaip individualiai pasirinkti mankštos pratimus, apsiskaičiuoti savo maksimalaus fizinio aktyvumo krūvio ribas (Fardy, Yanowitz, 1995). Lietuvoje dèl lèšu stygiaus tokios mokymo programos visuotinai nevykdomos. Be to, Lietuvoje atliktų tyrimų duomenimis, pagyvenusių asmenų nedomina grupine kūno kultūra. Jie mieliau mankštintųsi individualiai namie, tačiau neturi mankštos pratimų kompleksų aprašymų ir kitos metodinès medžiagos (Gailiūnienè, 1999).

Gauti duomenys patvirtina literatūroje nurodomą fizinio aktyvumo laisvalaikiu naudą ir reikšmę gyventojų sveikatai. Fiziškai aktyvūs gyventojai, taip pat vyrai, lyginant juos su moterimis, savo sveikata buvo linke vertinti geriau. Sveikatos vertinimo tarp lyčių skirtumas vyresnèje amžiaus grupejje siejamas su menopauzès sukeliamais pokyčiais moters organizme ir atsiradusiomis emocinèmis bei fizinèmis problemomis (Outram et 
al., 2004). Taip pat žinoma, kad tarp moterų yra didesnis sergamumas lètinèmis ligomis, stipresnè organizmo reakcija i stresą, vèliau pasireiškiantị depresija, o vyrai dažniau serga ūminèmis ligomis, dažnai besibaigiančiomis mirtimi (Leinonen et al., 1998). Literatūros duomenimis, moterų rūkymas, nutukimas, mažas fizinis aktyvumas lemia 10 kartų didesnę jų blogos sveikatos tikimybę (Meurer et al., 2001). Subjektyvaus sveikatos vertinimo bei psichosocialinių veiksnių sąsajas nustate ir kiti tyrejjai pastebėdami, kad geriau savo sveikatą vertina fiziškai aktyvūs, geros psichologinès ir emocinès būklès, mažiau nusiskundimų turintys bei geresnès socialinès ir ekonominès padèties asmenys (Astrom, Rise, 2001).

Teigiama, kad fizinè nejudra kasmet atneša daugiau nei du milijonus mirčių. Todèl Pasaulio sveikatos organizacija, kurdama lètinių neinfekcinių ligu profilaktikos strategiją, fizinio aktyvumo skatinimo programoms skiria ypatingą demesí. Norint atkreipti pasaulio visuomenès démesi $i$ fizinio aktyvumo problema, 2002 metų Tarptautinè sveikatos diena (balandžio 7-oji) buvo skirta fiziniam aktyvumui didinti (šūkis ,Judèk sveikatos labui") (Agita, 2002).

Atlikto tyrimo duomenimis, fiziškai aktyvūs gyventojai, lyginant juos su pasyviais, daugiau domejjosi literatūra apie aktyvią fizinę veiklą. Jie taip pat dažniau nei pasyvūs nurodè, kad norètuc klausytis paskaitų apie fizinių pratimų naudą. Tai tik dar kartą patvirtina literatūroje esančius duomenis apie individualių fizinių pratimų kompleksų ir švietimo apie sveikatą svarbą.

\section{IŠVADOS}

1. Tarp Kauno 35-64 metų gyventojų populiacijos pagal mankštinimosi ir sportavimo laisvalaikiu dažni bei trukmę fiziškai aktyvių vidutiniškai buvo $26,5 \%$. Pagrindinès nepakankamo fizinio aktyvumo priežastys - laisvalaikio stoka, pinigų susimokèti už sportavimo paslaugas trūkumas, tingèjimas.

2. Fizinio aktyvumo, tirtu socialinių-demografinių charakteristikų ir subjektyvaus savo sveikatos vertinimo lyginamoji analizè atskleidè, kad fiziškai aktyvesni (ir pagal dažni, ir pagal trukmę):

- 45-54 ir 55-64 m. amžiaus grupių tiriamieji, lyginant juos su 35-44 m. grupe (aktyviausi 45-54 m. amžiaus grupèje);

- visų amžiaus grupių vyrai, lyginant su moterimis;

- darbininkai, tarnautojai, verslininkai, lyginant juos su pensininkais, bedarbiais ir invalidais (aktyviausi darbininku grupeje);

3. Tarp asmenų, kurie savo sveikatą vertina kaip gerą ir labai gerą, buvo daugiau fiziškai aktyvių negu tarp vertinusiujų savo sveikatą blogai.

Padèka. Dėkojame Kauno medicinos universiteto Kardiologijos instituto Populiacinių tyrimų laboratorijos darbuotojams už sudarytą galimybę atlikti gyventojų fizinio aktyvumo tyrimą.

\section{LITERATŪRA}

Agita, M. (2002). Move for Health. World Health Organization. Geneva.

Ainsworth, B. E., Maskell, W. L., Leon, A. S. et al. (1993). Compendium of physical activities. Medicine \& Science in Sports \& Exercise, 25, 71-80.

Astrom, A. N., Rise, J. (2001). Socio-economic differences in patterns of health and oral health behaviour in 25 year old Norwegians. Clinical Oral Investigation, 5 (2), $122-128$.

Domarkienė, S., Jurėnienė, K., Petrokiené, Z. ir kt. (2000). Širdies ir kraujagysliu ligos: epidemiologija ir profilaktika. Kaunas.

Fardy, P. S., Yanowitz, F. G. (1995). Cardiac Rrehabilitation, Adult Fitness, and Exercise Testing (3 ed.). Baltimore: Williams and Wilkins.

Gaigalienè, B. (1999). 55-86 m. žmonių požiūris į fizini aktyvumą, fizini pajègumą ir sveikatą. Sporto mokslas, 2 (16), 50-54.

Gaigalienè, B. (1997). Vyresnio amžiaus žmonių subjek- tyvus kūno kultūros (mankštos) reikšmès vertinimas. Medicinos teorija ir praktika, 4 (9), 21-22.

Gailiūnienè, A. (1999). Anaerobinio energetinio komponento vieta sportininku darbingumo ir sveikatos vertinimo bendroje skaleje. Sporto mokslas, 2, 9-13.

Kuh, D. J., Cooper, C. (1992). Physical activity at 36 years: Patterns and childhood predictors in longitudinal study. Journal of Epidemiology and Community Health, Vol. 46, 114-119.

Leinonen, R., Heikkinen, E., Jylha, M. (1998). Self-rated health and self-assessed change in health in elderly men and women in a five year longitudinal study. Social Science and Medicine (Oxford), 46, 591-597.

Meurer, L. N., Layde, P. M., Guse, C. E. (2001). Self-rated health status: A new vital sign for primary care? $W M J$, 100, 35-39.

Naužemys, R., Saplinskas, J., Kniukšta, R. (2000). Fizinio aktyvumo paslaptys. Vilnius: Akstis. 
Outram, S, Mishra, G. D., Schofield, M. J. (2004). Sociodemographic and health related factors associated with poor mental health in midlife Australian women. Women and Health (New York NY), 39, 97-115.

Tamošiūnas, A. (1997). Gyvensenos rizikos veiksniai. Paplitimas, pokyčiu kryptys, prognozine reikšmé ser- gamumui miokardo infarktu ir mirtingumui dèl ìvairiu priežasčiu: hab. m. dr. disertacija. Kaunas.

Wold, B., Kannas, L. (1993). Sport motivation among adolescents in Finland, Norway and Sweden. Scandinavian Journal of Medicine and Science in Sports, 3, 283-291.

\title{
INTERFACE BETWEEN KAUNAS MIDDLE-AGED PEOPLE'S LEISURE-TIME PHYSICAL ACTIVITY AND SOCIO- DEMOGRAPHIC FACTORS
}

\author{
Edita Maciulevičienè, Kęstutis Kardelis \\ Lithuanian Academy of Physical Education, Kaunas, Lithuania
}

\begin{abstract}
The aim of the research: to assess interface between Kaunas middle-aged people's leisure-time physical activity and socio-demographic factors. The research was held in 2001-2005. Exploratory sample included 916 respondents (392 men and 524 women) who were selected using random assignment from Kaunas citizens (the sample of 1200 citizens of Kaunas was formulated with the Government's permission and according to the methodology of the Department of Statistics). Respondents aged 35-64 took part in the research. Interview method was applied to survey respondents' attitude towards leisure-time physical activity and sport, in addition, they were asked about the subjective health self-assessment, frequency and duration of physical activity during their leisure time. People who exercised or went in for sports during their leisure time once a week, once a month or even more rarely and the ones who exercised one hour or less a week were classed as insufficiently active. People who exercised or went in for sports during their leisure time every day, $2-6$ times a week or $2-3$ up to 7 hours a week were classed as physically active. Research data show that, in terms of frequency of physical activity, 23.8 per cent of Kaunas citizens aged 35-64 years were physically active, whereas 76.2 per cent were physically passive. In terms of duration of physical activity, 29.2 per cent of respondents were physically active and 70.8 per cent were passive. The respondents of the youngest age group (35-44) were less active compared with older ones. Men were more physically active than women (59.2 per cent and 40.8 per cent respectively, $\mathrm{p}<0.001)$. The main reasons that were indicated by respondents for insufficient physical activity were laziness and lack of time and money.

The subjective health of physically active respondents was better than health self-assessment among physically passive ones ( 75.8 per cent of physically active respondents and 61.8 per cent of physically passive ones assessed their health as good and very good, $\mathrm{p}<0.05$ ).

Health self-assessment among the youngest group of respondents was significantly better compared with the oldest one ( 35.7 per cent and 15.5 per cent respectively assessed their health as good and very good, $\mathrm{p}<0.001)$. There were significantly less women who assessed their health as good and very good compared with men $(21.4$ per cent versus 29.8 per cent, $\mathrm{p}<0.05)$.

The comparative analysis of leisure-time physical activity and socio-demographic factors showed that white-collar workers, blue-collar workers, and businessmen were more physically active (in accordance with both frequency and duration) than pensioners, the unemployed, and the disabled were.
\end{abstract}

Keywords: physical activity, self-rated health, socio-demographic factors.

Gauta 2006 m. gegužès 25 d.

Received on May 25, 2006

Priimta $2006 \mathrm{~m}$. rugsèjo $12 \mathrm{~d}$.

Accepted on September 12, 2006
Edita Maciulevičienè

Lietuvos kūno kultūros akademija

(Lithuanian Academy of Physical Education)

Sporto g. 6, LT-44221 Kaunas

Lietuva (Lithuania)

Tel +37068512032

E-mailedita@eik.1t 